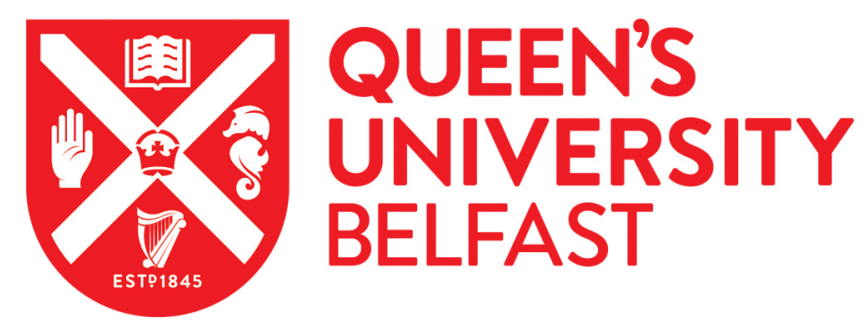

\title{
Resistance or Resilience? Tracking the Pathway of Recent Arrivals to a 'New' Rural Destination
}

McAreavey, R. (2012). Resistance or Resilience? Tracking the Pathway of Recent Arrivals to a 'New' Rural Destination. Sociologia Ruralis, 52(4), 488-507. https://doi.org/10.1111/j.1467-9523.2012.00573.x

Published in:

Sociologia Ruralis

Document Version:

Peer reviewed version

Queen's University Belfast - Research Portal:

Link to publication record in Queen's University Belfast Research Portal

Publisher rights

(C) 2012 The Author. Sociologia Ruralis () 2012 European Society for Rural Sociology

This is the peer reviewed version of the following article: McAreavey, R. (2012), Resistance or Resilience? Tracking the Pathway of Recent Arrivals to a 'New' Rural Destination. Sociologia Ruralis, 52: 488-507, which has been published in final form at

http://onlinelibrary.wiley.com/doi/10.1111/j.1467-9523.2012.00573.x/abstract. This article may be used for non-commercial purposes in

accordance with Wiley Terms and Conditions for Self-Archiving.

\section{General rights}

Copyright for the publications made accessible via the Queen's University Belfast Research Portal is retained by the author(s) and / or other copyright owners and it is a condition of accessing these publications that users recognise and abide by the legal requirements associated with these rights.

Take down policy

The Research Portal is Queen's institutional repository that provides access to Queen's research output. Every effort has been made to ensure that content in the Research Portal does not infringe any person's rights, or applicable UK laws. If you discover content in the

Research Portal that you believe breaches copyright or violates any law, please contact openaccess@qub.ac.uk. 
Resistance or resilience? Tracking the pathway of recent arrivals to a 'new' rural destination.

Modern and emerging economies increasingly, and often proactively, rely on migrants to fulfil growth and development objectives: within Europe the European Union has indicated the need for 20 million economically active migrants between 2010 and 2030. In North America, a place that was shaped by immigration, modern migrants provide seasonal labour to the agriculture sector in the USA (Simard and Jentsch 2009). Canadian regional migration policies complement affirmative action by federal government to counter an ageing and declining rural population (Simard 2009). Reflective of trends elsewhere, these movements are symptomatic of broader structural issues of demographic change; economic liberalisation and mobility; and enhanced communication links. In the absence of these migratory movements there is evidence of population decline and economic stagnation for remote and rural areas (Kandel and Cromartie 2004; de Lima et al. 2005; CRC 2007; Pollard et al. 2008; Jeng and Yang 2009; Lichter and Brown 2011).

International migration has long been experienced within Europe (see for instance Hoggart and Mendoza 1999, McDowell (2009) Wallace et al. forthcoming). However recent migratory movements within Europe as a result of its expansion to include A8 and A2 countries in 2004 and 2007 respectively resulted in migration on an unprecedented scale, pattern and pace. Much of this recent movement has been from East to West as individuals and families from Eastern European States moved to avail of new economic opportunities in a range of destinations and sectors including Norwegian agriculture (Rye and Andrzejewska 2010); Irish meat processing (Martynowicz and Jarman 2009) and small businesses in Germay (Miera 2008). Within these countries there has been evidence of settlement beyond urban centres to remote rural and small town areas including the Highlands of Scotland (de Lima et al. 2005), the mountainous areas of Northern Greece (Kasimis et al. 2003, Kasimis 2009); and small towns and rural localities within Northern Ireland (Jarman 2005; Martynowicz and Jarman 2009). Research indicates that migrants are attracted to new rural destinations in particular because of employment opportunities and 
often what are deemed to be reasonable standards and quality of living when compared to the country of origin (see for instance Parra and Pfeffer 2006; Rye and Andrzejewska 2010).

Much attention has been focused on pre-established destinations that give migrants the social and cultural capital to navigate their way through a new social context (Evergeti and Zontini 2006; Ryan et al. 2008; Pfeffer and Parra 2009) and often focusing on large-scale trends (Favell and Hansen 2002;

Feldblumer et al. 2006). Little is known about such migration pathways and how social systems can cope within newly receiving nations or indeed about the extent to which these 'new' areas will mature and longer term policy responses will be necessary. But with increasingly diverse communities existing within rural localities, the challenges of engagement through research and participation are heightened. This is particularly the case as formerly top-down agenda-setting and decision-making processes have been replaced by multi-level partnerships between the state and different interest groups within civil society (Warner 2001) and evidenced though the delivery and implementation of initiatives including the European Rural Development Programme (CEC 2005).

While offering a potential mechanism for rural development, recent arrivals to new destinations are not necessarily warmly welcomed by the host community. There is some evidence of localities embracing this change but overwhelmingly the research indicates resistance through negative attitudes or measures such as the creation of anti-immigrant ordinances (Chavez 2005; Pruitt 2009; O’Neil 2010). Even in places where migrants are not necessarily given a hostile welcome, they often find themselves segmented within a particular employment sector that is characterised by low pay, low skills and little security (Hoggard and Mendoza 1999). In these circumstances a breadth of interest groups including NGOs, churches, employers and friends become important support systems towards helping migrants access information and healthcare; availing of economic opportunities; and reducing isolation and inequalities (Jeanetta et al. 2009; Validivia and Dannerbeck 2009; Sandoval and Trabalzi 2010). These support mechanisms take on 
added significance in the context of reduced public sector expenditure and diminished welfare support (Pfeffer and Parra 2005).

This research investigates the way in which migrants' navigate social structures and institutions within a new destination. In so doing the article seeks to contribute to debates on migration and social integration. It is structured as follows: it considers the ambiguous concept of integration before presenting the study area and the empirical research. In the context of a new destination, the analysis continues by considering how host communities and migrants interact through and across a range of social structures and boundaries during the initial stages of migration as migrants establish themselves in a new society and neighbourhood and make sense of prevailing rules and regulations. The research reveals how civic society organisations offer the opportunity to lever additional resources and expertise - something that ought to appeal to cash-strapped governments. It concludes that government ought to respond to need, rather than simply focusing on that need by assuming a more proactive role such as ensuring policy coherency across departments or by actively implementing existing policies and initiatives.

\section{Perceptions and realities of migration}

Back in the early $20^{\text {th }}$ Century, while Park was less than optimistic about the status of the migrant, believing 'him to live in two worlds, in neither of which he ever quite belonged' (1928:893), he rightly pointed out that migration is about more than 'mere movement' (1928:886) indicating how the migrant is afforded new possibilities through new associations and new ventures. However, because the principle of migration may in particular contexts be a 'good thing', assurances cannot necessarily be given that the gains identified by Park back in the early $20^{\text {th }}$ Century and by more recent research will be realised (see for instance Portes 2010 and de Haas 2010 where positive outcomes include knowledge, financial and human remittances, political rejuvenation through voting). Some of the damaging aspects arising from migration include downward assimilation, regional depopulation, and the creation of transnational 
aspirations and communities (see for example Portes and Zhou 2005 in Portes 2010:1553). Putnam (2007) famously revealed increased levels of social isolation in the short-run within receiving communities that experience ethnic diversification. Indeed sudden demographic change can create tension including lowered social interaction and increased social disorder, particularly in rural communities that have historically been ethnically homogenous (Ream 2003; Broadway 2007; Gimpel and Lay 2008; McConnell and Miraftab 2009; McConnell 2010). Much of this research has been conducted in a North American context, within Western Europe there is a dearth of research on migration to rural areas and on the microlevel issues or human face of these processes (Smith and Favell 2006; Rye and Andrzejewska 2010).

\section{Social integration and migration}

The way in which different groups interact has long been of interest to scholars. Sociologically, positive connections between social actors are considered a normal condition of society (Tonnies 1883; Durkheim 1984 [1893]). The absence of cohesion, social norms, and at least a degree of common values is considered undesirable as it may lead to conflict and a general breakdown in the wider system of society (Durkheim 1984 [1893]). It is notable that many original sociological theories were articulated during a time of rapid transition from an agrarian-based economy and society to a more urbanised, industrial Europe and one where population mobility was instrumental to these transformations. Contemporary researchers of migration studies have called for a new epistemological basis for understanding recent patterns and processes of migration (see for instance Bauböck and Faist 2010, Bakewell 2010). One of the challenges is 'to understand the way individuals and organizations actually operate across cultures, and the costs and benefits of these arrangements' (Levitt 2004), the former issue being of particular interest to this analysis.

A variety of terms is currently used to examine the mobility of different groups, their interaction and the subsequent emergence of increasingly diverse social spaces. Migration is thus encapsulated within an array of frameworks including transnationalism, acculturation, assimilation and integration. Concerned 
with processes and meanings, these concepts recognise migration as a more intricate and rich process than in the past, involving individuals and also relating to wider social structures. This can give rise to problems of terminology (see for instance the special issue of the Journal of Ethnic and Racial Studies 2010). Debate is ongoing as migration theory advances and scholars strive to attain common understanding of associated terminology (Crul and Schneider 2010). This analysis aims to make a contribution to these matters.

Integration and assimilation are used respectively within European and Northern American discourse to refer to processes whereby migrants adapt to, and are adopted by, their new society. Assimilation is often conceived in negative terms following its historic application, and by applying the fairly rigid linguistic interpretation of 'becoming similar'. Implicit within this interpretation is that the society to which a new community assimilates is somehow superior and thus ought to be an aspiration for all immigrants. But as Alba (1999) points out, in reality American society has long been affected by immigrant ethnicity as much as immigrant ethnicity has affected that society and that is one of its distinctive features. A more sophisticated understanding of assimilation is to examine how 'an immigrant minority group can achieve parity of life chances with their peers in the ethnic majority' (Alba 2005: 21), such as through their ability to access services or to join the labour market. In this way assimilation is more about equality of opportunity and social inclusion than of social groups merging.

Evident throughout these conceptual frameworks is a degree of consensus that, rather than a linear oneoff movement from one place to another and expressed as loss and gain, migration in the modern era is more usefully conceptualised as a dynamic, fluid phenomenon. It is equally clear that processes of social interaction following migration have different features and the terms under which this [assimilation] 
happens vary from one societal context to another' (Alba 2005:41). A 'path-dependent process' (Alba 2005:41), it relies on the nature of the recipient society - social-structural; cultural; legal.

\section{Connecting with migrant groups}

The research informing this article explored the lived experiences of migrant workers in Northern Ireland. This 'requires talking to people, taking their perspectives, analysing their stories, and discovering the meaning of their actions through ethnography, participant observations, interviews, analyses of their diaries, letters and archives' (Chirkov 2009:97). Funded by the Nuffield Foundation, it was a qualitative study involving 18 interviews, three focus groups with migrants and one with supporting agencies. The payment of an honorarium to migrant participants provided token recognition of their contribution. It was conducted in two rural areas of Northern Ireland, one in the border area with the Republic of Ireland and the other located approximately mid-way between this and Belfast. Both areas had experienced a significant increase in migrant communities following the expansion of Europe in 2004.

Preliminary acquaintance was made with Susan at a conference organised by the local government to consider co-ordinating support for recent migrants. Susan was a volunteer from a Christian based voluntary body, Helpful that provides advocacy support as well as household items to families and individuals to people 'in need'. Referrals are made by its members, statutory agencies and voluntary organisations. It relies on volunteers, voluntary donations and fundraising to conduct its activities. As a gatekeeper, Susan provided initial access to migrants and from this a snowballing technique led to the identification of additional respondents.

This was exploratory research aiming to examine issues within a new migrant destination and for that reason the research design did not focus on a specific nationality, age-group or define a particular socioeconomic profile. However, three of the four focus groups were conducted with the Polish community, 
the largest Eastern European group in Northern Ireland (NISRA 2010). Among the 15 migrants that were interviewed, there was diversity in relation to nationality with the following countries represented: Lithuania, Poland, Bulgaria, Ukraine, Latvia and Slovakia. Their family circumstances varied to include singletons along with those in long term relationships with partners in Northern Ireland and some with partners in their home country. Ages spanned many different generations, from early twenties to midsixties. Respondents varied also in terms of motivation for moving and qualifications with a few working in professional posts, but the majority were employed in casual jobs. Interviewees had the option of doing interviews in their own language with the use of an interpreter or in English. The remaining three interviewees worked with migrants in support and advocacy roles.

All focus groups were approximately 2 hours in duration. One of the focus groups was conducted in the evening and it comprised of twelve individuals working with migrants through either supporting roles or service delivery including family support organisations, teachers, housing providers and interpreters. The remaining three focus groups were conducted with a Polish women's group over a period of three months at their regular meeting time. A core group of women were present during all three focus groups, and at any one meeting approximately ten individuals attended. Their ages ranged from early twenties to late fifties, some were married with young children, a few had families who were grown-up, others were single and a number were single parents. These focus groups were co-facilitated by the author and two interpreters, both of whom were also qualified psychologists. They were conducted in Polish with simultaneous interpretation.

Consent was granted from all participants in relation to their involvement in the research. All interviews and focus groups were recorded and transcribed with translation occurring as necessary. Pseudonyms were assigned to interviewees and organisations. The data was analysed and interpreted by reading and re-reading scripts, followed by a process of coding, so that emerging issues were identified and early ideas 
were elaborated or modified accordingly (Boeije 2010). Further methodological issues are explored in a forthcoming article.

\section{Northern Ireland: integration in a 'new' destination}

The expansion of Europe in 2004 resulted in Northern Ireland becoming a destination for Eastern European migrants (NISRA). One of the challenges for a new destination is that structures and systems are often not in place such as those for identifying the numbers of migrants that have arrived or predicting future patterns. The issue of ethnic monitoring is ongoing in Northern Ireland. Meanwhile predicting longer-term migration figures in the UK continues to challenge service providers and government agencies with debate over the degree of permanency of the movement of A8 nationals. Some commentators claim that this is short term and circular (Migration Policy Institute, 2009) and others suggest that it is part of a more permanent strategy to improve their, and their family's living conditions and overall life opportunities (McVeigh and McAfee 2009, Bell et al. 2009, Jurado 2009). Government predicts that the stock of international migrants is likely to remain stable (Department for Employment and Learning 2009) and current birth rates tend to confirm this prediction with one in ten babies in 2010 being born to mothers born outside of the UK and ROI.

Proportionately Northern Ireland attracted a larger number of A8 nationals than other areas of the UK (Beatty et al. 2006; Northern Ireland Statistics and Research Agency (NISRA) 2010). Not confined to urban centres, migrants moved to predominantly rural areas in Northern Ireland. The Dungannon local government region has the highest percentage of A8 population in Northern Ireland at $7.7 \%$ as compared with $2.2 \%$ across Northern Ireland, giving an overall estimated figure of around 39,000 people of A8 Central and Eastern European background (NISRA 2010). Health registration figures confirm this pattern of settlement as indicated in Figure 1 below. While the rate of immigration to Northern Ireland has declined, overall the region experiences net positive migration (NISRA 2010) and the births 
registered to mothers born outside the UK or Ireland continues to rise (NISRA 2010). It is estimated that migrants make up approximately $4.5 \%$ of the workforce (Russell 2012).

However, services remain under pressure: annual requests for health and social care interpretation grew from 1,850 in 2004-05 to over 63,000 in 2011-2012 (NIHSC Interpreting Service Yearly Statistics).

Insert figure 1 about here.

Past histories and specific exclusionary practices of communities are often linked with subsequent economic and social development of those areas and can therefore be illuminating for understanding contemporary attitudes, policies and practices (McConnell 2010). Northern Ireland is reputed for very gloomy reasons due to thirty years of, often violent, civil unrest that resulted in a stagnant economy and that maintained a long tradition of emigration. An increasingly diverse mix of groups represents the 'community' and it is no longer appropriate to consider it in binary terms of Protestantism or Catholicism (Ni Craith, 2002). Nonetheless an enduring essentialist interpretation of society prevails with a view of two cultures relating to the two majority groups, each of which is premised on a shared history and on joint experiences. This has in the past created problems with a tendency of one group is to reinforce community boundaries, both virtual and real as evidenced through different social networks; physical 
'peace' walls; distinct schools and segregated housing. On top of traditional ethno-religious community relations, issues of cohesion arise as a result of increased population diversity. Aspirations of a move to a 'new, more accountable public sector' (Review of Public Administration (RPA) 2006) is unlikely to successfully occur without active community participation. With statistics suggesting that migrants are a permanent fixture within society, such participation will involve the traditional majority groups, but also more recent arrivals.

\section{Attitudes to migrants}

Baubock's (1994) observation that integration carries a connotation of a society that is well ordered is particularly germane to NI where this seems to be an inherent assumption. There is little attention paid to the fact that existing society is divided and has had major problems in the past. Although most people in Northern Ireland believe that migrant workers make their society open to new ideas and cultures (Gilligan 2008), it is also the case that Northern Ireland has in the past been dubbed the race-hate capital of Europe. This label denotes the massive rise in racist attacks that emerged during and subsequent to the peace process in the late 1990s (Douglas in Lentin and McVeigh 2006). Ongoing distrust and tension is evident with the general public being less welcoming of the rights of EU citizens to live and work in Northern Ireland in 2008 than in the previous year'; Meanwhile racial crime and incidences have persisted since 2005 (OFMDFM 2010a).

\footnotetext{
${ }^{1} 67$ per cent of respondents to the Good Relations Indicator survey stated that they were very or fairly welcoming of the rights of EU citizens to live and work in NI, compared to 76 per cent in 2007.
} 
Changed circumstances alter the position of migrants and of the destination areas not least in pure neoclassical economic terms, but also regarding culture and wider societal trends and opportunities. An employee of the housing agency expresses this notion:

'in the public sector I think we are in safe jobs, there is a feeling that we're protected from the recession...but I know people who are in the building trade and they would be fairly tolerant, decent people and once you mention migrant workers they go off on one. They say that wages are undercut because of migrant workers, we're subsidising them and I'm wondering, it's ok for us to sit here in this safe room and say that we're tolerant, but if someone came in here and said that our jobs were to be cut by $30 \%$ I wonder would our tolerance start to drop? Or if they were saying we don't need you now because your work is being put to contract, so it's very easy to sit from our comfortable position and say that we're tolerant, but views can change. I do agree with you that we need to get the message out there that this is good for NI, it's good for our society and it's good for our economy and it's good in all them [sic] areas. That message particularly in the current economic downturn is going to get more and more difficult to get across' (Dave Northern Ireland Housing Executive).

Even if migrant competition is not real, its perception will result in altered behaviour and opinions. It can lead to negative stereotypying and discrimination within social domains such in the workplace or in schools. Altered public attitudes have significant effect on politics, government and public discourse. This has been witnessed recently within Germany and the UK with speeches from national leaders on matters relating to migration. For instance Chancellor Merkel called for immigrants to assume more responsibility for integration into German society during her speech given to fellow political party members in Germany (Merkel speech, last accessed 20 ${ }^{\text {th }}$ April 2011. http://www.guardian.co.uk/world/2010/oct/17/angelamerkel-german-multiculturalism-failed Speech delivered 17.10.11). Continuing the theme of integration, albeit in a slightly different manner and some months later, Prime Minister Cameron delivered a strong 
message on immigration seeking to achieve 'good immigration, not mass immigration' by ensuring 'real integration'. He outlined his government's plans to substantially reduce migration to levels more akin to those experienced during the 1980s and 1990s by addressing issues relating to education, services, economy and employment. The speech was dripping with political rhetoric as it evoked images of 'discomfort and disjointedness in some neighbourhoods' and of serious social pressures across certain communities (http://www.guardian.co.uk/politics/2011/apr/14/david-cameron-immigration-speechfull-text, last accessed $20^{\text {th }}$ April 2011. Speech delivered 14.04.11). Popular opinion affects politics which in turn influences the way in which migration is managed and legislated for, potentially curtailing the ability of migrants to participate in social and economic life without discrimination as a result of their minority or ethnic status.

Connecting with a new society: getting help and establishing life in a new place

This section examines how migrants make sense of, and survive within, a new setting as they settle into a new society and neighbourhood and make sense of prevailing rules and regulations. It considers the legislative framework for and initial navigation of migrants following their arrival to Northern Ireland.

\section{Managing and legislating for migration}

Equality legislation within Northern Ireland provides a sound framework for guaranteeing human rights, equality and participation. Although borne out of political and religious tensions between Protestant and Catholics, it has attracted national and international prominence because of its pioneering nature (Chaney and Rees 2004; Hill et al. 2006). Section 75 of the Northern Ireland Act 1998 is a mainstreaming approach that places positive duties on public authorities to have due regard for the promotion of equality of opportunity in formulation of policy and this includes promoting good relations between different racial groups. Meanwhile the Racial Equality Strategy in Northern Ireland (OFMDFM 2005) aims to provide equal 
access to public services for minority ethnic groups. It is the case then that community relations are increasingly considered in broader terms than they were in the past with the label 'good relations' used to encompass minority as well as the majority communities. Government recognises that social cohesion can only be achieved through the involvement of all groups, including migrants, and the traditionally divided Protestant and Catholic communities (OFMDFM 2010b). Further, OFMDFM cites the importance of the private and third sectors in achieving its economic development objectives.

However, a separate and ad hoc approach within key strategy government documents in Northern Ireland is evident. Economic development strategies failed to identify the potential contribution of the underutilised migrant labour pool and at the same time another government department emphasised the importance of these communities in playing a role in society. Specifically the Economic Strategy for Northern Ireland (DETI 2012a) and the accompanying Action Plan (DETI 2012b) fails to mention migrants as a potential economic resource while the Racial Equality Strategy for Northern Ireland is focused on migrants' needs (OFMDFM 2005, 2006). The Racial Equality strategy recognises that poor levels of English can cause barriers to accessing key services including health, education and employment. It would thus be reasonable to consider that government might explicitly cite the importance of language training for economic development, something which it fails to do. Equally neglectful, the Economic Strategy seeks to improve the level, relevance and use of skills and of foreign language skills. However it makes no reference to a qualification framework that would allow for the mapping of qualifications between different countries or does it cite the untapped skilled labour market that exists within the migrant community. These documents set the over-arching framework within which different institutions and individuals operate. However some of the rather general claims would benefit from clarity on how exactly migrants may make a potential input to the local economy including their pathways to employment, routes out of low wage jobs and available training options. In this way connections could be made between different 
policy instruments. Some of the problems arising from an ad hoc policy approach are crystallised when migrants seek employment as the following sections illustrates.

\section{Employment and qualifications}

The potential contribution of migrant communities to the economy was not always realised. Many of those interviewed held a number of degrees but most of those in employment were doing blue collar or menial jobs, often in poor conditions. For instance Audra had completed University level qualifications in accountancy in Lithuania but was working as a cleaner in Armagh. Similarly Tvesta, an Agricultural Economist from Bulgaria, was employed in jobs far below her skill area working as a kitchen assistant for a primary school in the morning and then as a cleaner in a hospital during the evenings. Then, at the weekends she worked in a local restaurant. She describes her feelings about this situation:

'That makes me sad, because I spent so many years studying and you come over and it's hard to find a place to work with your qualifications. First of all to find a job with the equivalence of your qualification, it's hard. I did that, but they put me at one level less than I had and it's quite hard to get registered in an economic organisation or association and to start working as an economist... I [am qualified] to teach people in colleges and higher education. And the other thing is that I will probably try and get my diploma for here just to get registered and I will probably try and cover some exams. It's hard to do because always if you go to a course they will look and say but there is no point because they say you have this already there is no point you doing this course and the employer will say that you need to do the course. So one person is saying one thing and the other [person is saying] something else'.

While government has introduced a scheme to assist in the recognition of qualifications across national boundaries, this is only fairly recently and the evidence would suggest it is little understood (Wallace et 
al. forthcoming 2012). The problem is that when individuals arrive they seek immediate employment or have already set something up and so they tend to take whatever jobs they can find in the short term. They often become locked into that position - they do not understand the system sufficiently to pursue the options of having their qualifications recognised or they may not feel empowered to apply for the posts that they might actually be qualified to undertake (FG Polish women, FG support agencies). Some individuals such as Stanislow make conscious decisions to progress so that and move jobs a number of times until they find employment in which they are content. In one of his posts his employer promoted him within the company, but he eventually left that organisation as he wanted to find work that used his language skills.

Even in a place where equality legislation is considered innovative and all-encompassing, many individuals endured adverse levels of hardship as they pursued economic opportunities. This is described by Mariya as she recounts her visa ordeal:

'There were 13 of us from the Ukraine, this lady from the agency promised us jobs if we paid her the money... So we were working just outside Dublin, I can't remember the name of the place. It was a village, there was maybe a house ...So we went to the factory and we sliced mushrooms all day and then we were brought back to the flat...The first boss didn't want to give me my visa when it was finished, he kept promising and but wouldn't give it to me. So some of the ladies got a journalist from Dublin and came and filmed what was happening'.

Mariya's experience highlights how employers may exploit their position to create a situation where employment is tied to accommodation. They may then justify the retention of individual wages as an exchange for rent which is often charged at a higher rate than the market value. Maja also describes more exploitation associated with employment. She left Lithuania because of an abusive relationship with her husband and she applied to an employment agency for a job: 
‘I answered a newspaper advert in Lithuania and paid money to get a job in Ireland. The man said that I would have the right papers and I would have a job when I came to Northern Ireland. It was for work in a chicken factory in Portadown. But there was no job; that man disappeared.... I arrived in Portadown, I lost my phone, it was a terrible day, the worst. So I had nowhere to live and nowhere to work. But I found some very good people, fantastic people. A very good policeman took me to Armagh and left me to at the hostel... Here I met Rosa from Russia. There were also lots of people there to help with all the papers and the forms. These were very good people, very good and they helped me to find jobs'.

Maja's experiences very neatly elucidate the way in which none of these areas of daily life sit independently, but different aspects of society intertwine. Questions emerge over where and with whom, responsibility lies for assisting migrants.

Individuals working in social care were notably frustrated, as articulated by Angela a health professional:

'I know Polish people who are qualified Psychologists and that, who I know that they could be integrated into the team and I know that we should be in a position so that they could help to provide the services that we offer to their own community, but it's like banging my head off a brick wall, no-one will listen.'

The employment of ethnic minorities within health and social care has great potential to achieve cultural competence in service delivery (see for instance Weaver 1999) thereby ensuring better access to services across the range of client groups. While interpretation may provide a short term solution, in the longer term as 'new' destinations mature, it is imperative that particular social groups are not excluded. This requires employing 'cultural intelligence' (Barnard and Turner 2011: 8) so that services are re-designed to take account of the diverse needs of the different users. 


\section{Civil Society}

Within Northern Ireland there was a general feeling that institutions were unable to cope with the pressures that were being placed on them due to a lack of anticipation of the volume of migrants following the expansion of Europe. So for instance language classes which are recognised by government as a key component of integration were deemed inadequate and over-subscribed (Maryia, Audra, Maja). Meanwhile

'...the European Union gates were opened up and proper policies and procedures were not put in place for both people on the ground and for employers...And if we have a group of people out there who do not actually know the facts and figures or the statistics and what is going on then those problems are always going to arise' (FG1, Susan).

Civil society has been defined as 'the multitude of associations around which society voluntarily organizes itself and which represent a wide range of interests and ties. These can include community-based organisations, indigenous peoples' organisations and non-government organizations (OECD 2007). These different groups cooperate to generate community benefits in response to identified issues (Morton 2003). Overall the research found that migrants sought help from a range of governmental (housing agency (NIHE), Benefits Office) and non-governmental organisations (Citizens Advice Bureaus; Community Centre and Trade Unions) and from private sector employers. Indeed government led job centres were frequently cited as the point of contact in problem situations. But as one individual pointed out: people need to know what to expect and the questions that they should ask; this was not always possible. Consequently many people, including Maryia made initial contact with civic society organisations from where they were signposted to appropriate government agencies or made aware of employment opportunities: 
'So I came to Armagh...It was very cold, it was a very bad time (Maryia cries). I was in bed with lots of different clothes and putting a lot of blankets on. There was only an electric heater, but I had no money...I had to move into the hostel, thanks to those good people. They are very good people, they gave me so much help. I was out looking for work all day and then I would come back and some of these people were cooking me supper. When it would come to 6 o'clock then we would all come together, lots of people from all over, from Russia, Poland and from Ireland. When I would come back they would say that my food was in the microwave. So I had to do some work, everybody had to help - cleaning the kitchen this type of thing. I was so nervous, I wasn't able to sit and watch TV. I couldn't sit down, I was scared, and my visa had ended. I wanted to help my daughter, I couldn't see her. It was a terrible time' (I\#8). And subsequently civic society filled a gap when it came to renewing her visa...'[Susan] (from SVP) helped a lot, the church helped, and the local politicians wrote to the Embassy. I had a lot of help, there are a lot of good people here in Armagh'.

Migrants believed that civil society organisations were effective in providing informal networking opportunities and were particularly useful for exchanging essential information on navigating bureaucracy and surviving in general. For instance many of the migrants interviewed belonged to religious organisations including the Catholic Church (attending sporadically at Easter or Christmas). The Catholic Church provided backing beyond religious instruction:

'Well a Lithuanian priest comes from Dublin once a month and we meet in St. Patrick's Grammar School just talking, having some food. Just last week we had a special thing for the children, painting eggs and doing these things. There's also a Lithuanian paper, a newspaper the newspaper is printed weekly in Dublin and a group of volunteers organises the get together...)' (Zusane). 
Equally some of the interviewees indicated how, when they needed help with paperwork such as passports or Worker Registration Scheme forms, they often went to the local priest. Others made friends through the church.

\section{Individual responses and actions}

There was evidence of extremely active agents within the host society as well as among migrant groups. For instance a number of discos had been arranged by a group of Polish nationals and held in a local pub. Meanwhile migrants working at a local petrol station learned about the support offered through SVP as a result of Susan's 'casual chats' with them when she was picking up groceries. These exchanges were not entirely spontaneous as Susan spoke of a deliberate strategy to engage with these people. This was driven by altruistic motives as Stanislow explains:

'[Susan] is helping [sic] people all her life, I mean it's just (he sighs)...she has a heart the size

of that room. But she told me one day, [Stanislow] always treat people the way you would like to be treated. That's her motto'.

Individual effort was instrumental in setting up a Bulgarian Parent and Toddler group with that group's co-ordinator making arrangements to set up meetings in her spare time. She was already busy with two jobs and a young child but managed to find time to negotiate with Susan so that the Helpful facilities were made available free of charge to the embryonic group for their monthly meetings. Similarly the Polish women's group that participated in three focus groups was wholly reliant on proactive migrants.

The research shows how support for migrants was not automatically structured or pre-meditated; serendipity, general warmth and considered actions of the local residents clearly have an affirmative role 
in the life stories of migrants. Casual conversations with others in public spaces such as doctors' waiting rooms or at school events often led to valuable knowledge of the system and society. Rasa elucidates:

What about housing when you came here?

'Well it was actually my friend here in Armagh...'

...was that through [Linas] who was working here at the time?

'Yes, my cousin stayed at the boss' farm house, but there was not enough room. Then my children started school and the teacher was very friendly. She has a spare house for renting. It's a very nice house and we have been there for 5 years...Even just at the bank, I didn't know how to open a bank account. And so I went with a book and they said 'ok, so you want to open a bank account' so yes, they all helped...Also my neighbours, they were very good.

And where do you go to get information about the things that you need just to live here?

I found that all by word of mouth, so my children's teacher that we rent the house from. So she told me everything.'

An institutional backdrop is essential and in valuable in its own right. Its real worth is perhaps best perceptible in the way in which it is understood, interpreted and enforced by social actors:

'I know there's one family and the Council said that technically they shouldn't be supporting them because there's no WRS, so legally they could and should step away from them, because there's no hope of getting a job, so there's all these things and they could step away, but if they step away then there could be 5 kids on the street and that would be bad, it would 
be bad for the children and for the Council profile. So I know they're really worried about that in the next year, that it's just going to explode' (Ted, migrant support group FG 1).

The absence of checks and balances to manage and complement structures and legislation can offer opportunities for flexible interpretation being somewhat dependent on the individuals concerned. This can work in a positive way; alternatively it can mean additional hardship for migrants when minimum standards are not enforced. Interviewee's recounted tales of cramped living conditions; accommodation tied to employment; and employment below minimum wage.

\section{Conclusions}

This article analysed the way in which migrants' navigate social structures and institutions within a new destination as a means of understanding processes of integration. The response across civic society organisations, government agencies and private sector bodies was shown to be quite different. Broadly we see private sector agents seizing market driven opportunities; civil society organisations reacting to new and unfolding events; and government agencies operating distinct policy strategies, struggling to meet unanticipated demand and to understand the regulatory framework. Across these sectors, the role of individual agents was notable with evidence of some flexing the rules along the way, as a means of supporting often vulnerable migrants. It is evident that left to its own devices the market will not necessarily realise the economic and social value of migrants that previous research suggests will flow in the longer term (House of Lords 2008).

Broadway's (2007) claim that geography and macro-migration policies both impact on the way in which rural communities are transformed resonated greatly with this research. It showed how boundaries for action are clearly defined through legal and organisational structures indicating what is, and is not, acceptable within the recipient society. The value of these structures is not to be underestimated. 
However, and at the risk accusations of 'over agentising' (Bakewell 2010), the human face of migration should not be forgotten. Individuals across different sectors offered remarkable levels of support, displaying a very human face to migration. Rather than being burdened by administrative rules these agents were willing to make judgements about the greater good and the welfare of migrants. Private sector agents seize market-related opportunities to employ migrants. This may lead to migrants' economic mobility, but it can also result in migrants becoming locked into low-pay, low-skilled employment. In this latter scenario regulations are often flouted and poor employment or discriminatory practices prevail. It may be the case that individuals and employers defy rules in circumstances where they know penalties are avoidable or so unlikely as to pose a minimal risk, but this merits further investigation.

Even though civil society organisations are constrained by budgets, they are more nimble and appear to have more capacity than statutory sector agencies to respond immediately to unexpected needs. The evidence from the research shows how these organisations endeavoured to plug the gaps in statutory service provision. However they rely on basic infrastructure that is established by government and includes equality legislation, population monitoring and enforcement of regulations.

Government plays an important role in helping to create a context that encourages positive integration. Policy coherency and synergy across government is a crucial backdrop along with robust legislation and data monitoring. Institutions respond to emerging needs and demands which are often unknown and so services often struggle to keep up with unexpected increases in service demands (Krannich and Greider 1990 in Broadway 2007). Without adequate monitoring of migrants as is the case in Northern Ireland, service providers will remain constrained by historic client figures and budget projections that are outdated even before they are fully operationalised. Meanwhile legislation alone cannot achieve positive integration by ensuring equal life chances for different social groups. The key is to ensure meaningful 
monitoring of the implementation and intend of such strategies, otherwise there is a danger they remain paper exercises with little impact on policy and practice (see Craig et al., 2012). This would seem to be the case in Northern Ireland where barriers to individuals gaining employment that utilises their qualifications and skills still seem to exist even with the establishment of a framework to recognise qualifications across Member States. The way in which such measures are designed and promoted by government and implemented by agents would seem to be critical.

New solutions that do not valorise majority groups offer a way forward for new destination areas as they become 'mature' migrant destinations. Hall (1990) reminds us of the importance of the past as well as the future for shaping culture. By merit of their status as a minority group, their skills such as language or knowledge such as cultural understanding can be used to help deliver some of the services that new destinations are constrained to deliver. This should be achievable in the context of public sector reform where services are increasingly delivered in partnerships between government and third sector organisations (OECD 2005). Supporting migrants' involvement in a society will have the additional benefit of enhancing communication with other groups in the recipient society. Basic consideration of Allport's (1954) contact hypothesis would indicate improved social relations.

A number of matters emerge from the research with particular significance for rural areas and small towns where there has been little or no history of immigration. Previous research has indicated the limited institutional capacity of such 'new destinations' to accommodate the needs of a newly diverse population and of the importance of past history in shaping politics and influencing migrants' reception within an area. Rural areas and small towns do not have the critical mass of other places, and so their institutional capacity to absorb increased diversity may be lower than that of urban centres. For new destinations, predicting demand and matching services can be tricky as historical circumstances do not necessarily reflect current requirements. The legislative framework lies clearly within the bailiwick of government; 
less clear however, is the question of who ought to assume a more proactive role by reaching out to migrants and thereby understanding and responding to their needs. Migrants to Northern Ireland arrived into a stable society, but it was one complicated by delicate community relations between two dominant groups and with little history of immigration. A robust equality framework was shown to be insufficient to encourage active involvement of new migrant communities, highlighting the distinction between recognising difference and doing something about it (Taylor 1994). Acceptance of difference needs to be reconciled with a political intent to ensure such difference does not become the basis for inequality. One opportunity might be stronger attempts to engage with minority groups within truly innovative rural development initiatives where frames of reference take account of diverse cultural and social norms and so more accurately reflect the population of a particular area. 


\section{References}

Alba, R. (1999) Immigration and the American Realities of Assimilation and Multiculturalism. Sociological Forum Vol. 14. No. 1 pp. 1573-7861.

Alba, R. (2005) Bright vs. blurred boundaries: Second-generation assimilation and exclusion in France, Germany, and the United States. Ethnic and Racial Studies Vol. 128. No. 1 pp. 20-49.

Allport, G. W. (1954). The nature of prejudice. Cambridge, MA: Perseus Books

Bakewell, Oliver(2010) 'Some Reflections on Structure and Agency in Migration Theory', Journal of

Ethnic and Migration Studies, Vol. 36: 10, pp.1689 - 1708.

Barnard, H. and Turner, C. (2011) Poverty and ethnicity: A review of evidence. York: Joseph Rowntree Foundation.

Bauböck, R. (1994) The Integration of Immigrants. Report for the Council of Europe, CMDG (94) 25 E, Strasbourg.

Bauböck, R. and Faist, T. (eds.) (2010) Transnationalism and Diaspora. Concepts, Theories and Methods. Amsterdam University Press, Amsterdam.

Beatty, R., Fegan, G., and Marshall, D. (2006) Long-term international migration estimates for Northern Ireland (2004-5) - Sources and Methodology. Belfast: NISRA.

Boeije, H. (2010) Analysis in Qualitative Research. London: Sage Publications. 
Broadway, M. (2007) Meatpacking and the transformation of rural communities: A comparison of Brooks, Alberta and Garden City, Kansas. Rural Sociology Vo. 72(4) pp. 560-582.

Chaney, P. and Rees, T. (2004) The Northern Ireland Section 75 Duty: An International Perspective. Paper presented to the Section 75 Equality Duty - An operational review conference. Belfast.

Chavez, S. (2005) Community, ethnicity and class in a changing rural California town. Rural Sociology Vol.70(3), pp. 14-55.

Chirkov, V. Critical psychology of acculturation: What do we study and how do we study it, when we investigate acculturation. Journal of Intercultural Relations, Vol. 33 pp. 94-105.

Commission for Rural Communities (2007) Migrant Workers in Rural Areas. CRC Briefing Paper. Cheltenham: CRC.

Crul, M. and Schneider, J. (2010) Comparative integration context theory: participation and belonging in new diverse European cities. Ethnic and Racial Studies, Vol. 33 (7) pp. 1249-1268.

Department of Enterprise, Trade and Investment (2012a) Priorities for sustainable growth and prosperity. Building a Better future. Belfast: Northern Ireland Executive.

Department of Enterprise, Trade and Investment (2012b) Northern Ireland Economic Strategy: Comprehensive Action Plan. Belfast: Northern Ireland Executive.

de Haas, H. (2010) The internal dynamics of migration processes: a theoretical inquiry. Journal of Ethnic and Migration Studies, Vol. 36 No. 10 pp.1587-1617. 
De Lima, P. Jentsch, B., and Whelton, R. (2005) Migrant Workers in the Highlands and Islands, UHI PolicyWeb and National Centre for Migration Studies.

Department for Employment and Learning (2009). The Economic, Labour Market and Skills Impacts of Migrant Workers in Northern Ireland. Oxford Economics with FGS McClure Watters and Perceptive Insight Market Research. Belfast: DEL. Available at: http://www.delni.gov.uk/the_economic_labour_market_and_skills_impact_of_migrant_workers_in_n orthern_ireland.pdf

Durkheim, E. (1984 [1893]) The Division of Labor in Society. New York: Free Press.

Evergeti, V. and Zontini, E., 2006. Introduction: some critical reflections on social capital, migration and transnational families. Ethnic and Racial Studies, 29(6), 1025-1039.

Favell, A. and Hansen, R. (2002) Markets against politics: Migration, EU enlargement and the idea of Europe in EU enlargement and East-West migration, Vol.24(4), pp.581-601.

Feldblum, M., Smith, M. P. and Favell, A. (2006) 'The human face of global mobility: a research agenda' intro to The Human Face of Global Mobility, Smith, M. P. and Favell, A. (eds) Transaction Press, pp.1-25.

Gilligan, C. (2008) Migration and migrant workers in Northern Ireland. ARK Research Update 53, Belfast: ARK (http://www.ark.ac.uk/publications/updates/update53.pdf)

Gimpel, J.G. and Lay, J.C. (2008) Political Socialization and Reactions to Immigration-Related Diversity in Rural America. Rural Sociology Vol. 73 (2) pp.180-204.

Hall, S. (1990) Cultural Identity and Diaspora. In: Jonathan Rutherford (ed.), Identity, Community, Culture, Difference, pp. 222-237. Lawrence \& Wishart: London. 
Hill, M., McAuley, C., McLaughlin, E. and Porter, F. (2006) Eighty years of talking about equality in Northern Ireland: A history of equality of discourses and practices. Equality and Social Inclusion in Ireland Project: Working Paper No. 5.

House of Lords (2008) Select Committee on Economic Affairs. 1st Report of Session 2007-08. The Economic Impact of Immigration. Volume I: Report HL Paper 82-I. Published by the Authority of the House of Lords. London: The Stationery Office Limited

Jeanetta, S.C., Martinez, D., Valdivia, C., Flores, L.Y. and Dozi, P. 2009. Latinos in the Midwest: Newcomers Assets, Expectations and Integration Policies. Presented at the Julian Samora Research Institute 20th Anniversary Conference: Latino(a) Communities in the Midwest. East Lansing, Michigan. November. http://www.jsri.msu.edu/images/JeanettaMartinezPPP.pdf Growth and Change in Arkansas' Hispanic Population. Printed by the University of Arkansas Cooperative Extension Service Printing Services.

Jarman, N. (2005) Changing Patterns and future planning. Migration and Northern Ireland. Institute for Conflict Research Working Paper No. 1.

Jeng, L. and Yang, T. Taken by surprise: new immigrants in the rural United States in Jentsch, B. and Simard, M (2009) International Migration and Rural Areas, Cross-National Comparative Perspectives. Surrey, England: Ashgate, Ch. 2 pp.17-42.

Kandel, W. and Cromartie, J. (2004) New patterns of Hispanic settlement in rural America. Rural Development Research report Number 99. Washington DC: United States Department of Agriculture.

Kasimis, C.A., Papadopoulos, G. and Zacopoulou, E. (2003) Migrants in Rural Greece. Sociologia Ruralis Vol.43(2) pp. 167-184 
Kasimis C.A., (2009) From Enthusiasm to Perplexity and Scepticism: International Migrants in the Rural Regions of Greece and Southern Europe Canada in Jentsch, B. and Simard, M (2009) International Migration and Rural Areas, Cross-National Comparative Perspectives. Surrey, England: Ashgate, Ch. 4 pp. 75-98.

Lentin, R. and McVeigh, R. (2006) After Optimism? Ireland, Racism and Globalisation, Dublin, Metro Eireann Publications.

Levitt, P. (2004) Transnational Migrants: When 'Home' means more than one country. Migration Information Source, Oct. http://www.migrationinformation.org/feature/display.cfm?ID=261, last accessed $26^{\text {th }}$ May 2011.

Lichter, D.T. and Brown, D. L. (2011) Rural America in an urban society: Changing spatial and social boundaries. Annual Review of Sociology, Vol. 37: pp.27.1-27.28.

Martynowicz, A. and Jarman, N. (2009) New Migration, Equality and Integration - Issues and Challenges for Northern Ireland. Belfast: Equality Commission for Northern Ireland.

Miera, F. (2008) Transnational Strategies of Polish Migrant Entrepreneurs in Trade and Small Business in Berlin. Journal of Ethnic and Migration Studies Vol. 5 pp. 753-770.

Migration Policy Institute (September 2009) Migration and the Global Recession, Washington DC: MPI,

http://www.migrationpolicy.org/pubs/MPI-BBCreport-Sept09.pdf)

Morten, L. W. (2003) Small Town Services and Facilities: The influence of social capital and civic structure on perceptions of quality. City and Community 2 pp.101-120. 
McConnell, E.D. and Miraftab F. (2009) Sundown Town to 'Mexican Town': Newcomers, Old Timers, and Housing in Small Town America. Rural Sociology 74 (4) pp. 605-629

McConnell, E. D. 2010. Racialized Histories and Contemporary Population Dynamics in the New South. Chapter 2 in Cameron D. Lippard and Charles A. Gallagher (eds.) Being Brown in Dixie: Race, Ethnicity, and Latino Immigration in the New South. Boulder, CO: First Forum Press.

McDowell, L. (2009) Old and New European Economic Migrants: Whiteness and Managed Migration Policies. Journal of Ethnic and Migration Studies, 35(1): 19-36

Ni Craith, M. (2002) Plural Identities -Singular Narratives: The Case of Northern Ireland. Berghahn.

Northern Ireland Statistics and Research Agency (NISRA) (2010) STATISTICS PRESS NOTICE - MIGRATION STATISTICS NORTHERN IRELAND, 2009. $25^{\text {th }}$ November 2010, Belfast

NISRA (2009) Northern Ireland Neighbourhood Information Service: Data Catalogue http://www.ninis.nisra.gov.uk/mapxtreme/DataCatalogue.asp?button=Population

Office of the First Minister and the Deputy First Minister (OFMDFM) (2005) A Racial Equality Strategy for Northern Ireland. Belfast: OFMDFM.

OFMDFM (2006) A Racial Equality Strategy for Northern Ireland 2005-2010 First Annual Implementation Action Plan - 2006 Belfast: OFMDFM.

OFMDFM (2010a) Good Relations Indicators, 2009 Update. Belfast: OFMDFM.

OFMDFM 2010b Programme for Cohesion, Sharing and Integration. Belfast: OFMDFM

OECD (2005) Modernising Government. The Way Forward. Paris: OECD. 
OECD (2007) Glossary of statistical terms: Civil Society Organisations. Available at http://stats.oecd.org/glossary/detail.asp?ID=7231, last accessed 25 May 2011.

O'Neill, K. (2010) Hazleton and beyond: why communities try to restrict immigration. Migration Information Source, Nov. http://www.migrationinformation.org/Feature/display.cfm?ID=805, last accessed $26^{\text {th }}$ May 2011.

Park, R.E. (1950) Race and Culture. Gencoe:The Free Press.

Park, R.E. (1952) Human communities: the city and human ecology. Glencoe III: Free press.

Pfeffer, M.J., and Parra, P. (2005). Immigrants and the Community: Community Perspectives. Development Sociology Department, College of Agriculture and Life Sciences, Cornell University.

Pfeffer, M.J., and Parra, P. (2009) Strong Ties, Weak Ties, and Human Capital: Latino Immigrant Employment Outside the Enclave. Rural Sociology, 74(2):241-269.

Pollard, N., Latorre, M. and Sriskandarajah, D. (2008) Floodgates or turnstiles? Post-EU enlargement migration flows to (and from) the UK. London: ippr.

Portes, A. (2010) Migration and Social Change: Some Conceptual Reflections. Journal of Ethnic and Migration Studies, Vol. 36 No. 10 pp. $1537-1563$.

Pruitt, L. R. (2009) Latina/os, Locality and Law in the Rural South, 12 HARVARD LATINO LAW REVIEW 135

Putnam, R.D. (2007) E Pluribus Unum: Diversity and Community in the Twenty-first Century The 2006 Johan Skytte Prize Lecture Scandinavian Political Studies 30 (2) 137-174 available at http://www.blackwell-synergy.com/doi/abs/10.1111/j.1467-9477.2007.00176.x 
Ream, R. K. 2003. Counterfeit Social Capital and Mexican-American Underachievement. Educational Evaluation and Policy Analysis. 25(3):237-262.

Review of Public Administration (2006) website (http://www.rpani.gov.uk/) Accessed 16.11.06.

Russell, R. (2012) Migration in Northern Ireland: an update. NI Assembly Research and Information Service Research Paper NIAR 10-12. Belfast: NI Assembly.

Ryan, L., Sales, R., Tilki, M. and Siara, B. (2008) Social Networks, Social Support and Social Capital: The Experiences of Recent Polish Migrants in London Sociology, Vol. 42, No. 4, 672-690

Rye, J.F. and Andrzejewska, J. (2010) The structural disempowerment of Eastern European migrant farm workers in Norwegian agriculture. Journal of Rural Studies 26 pp.41-51.

Sandoval, G. and Trabalzi, F. (2010). The exotic other: Latinos and the remaking of community identity in Perry, lowa. Community Development 41(1): 76-91.

Simard, M. (2009) Retention and departure factors influencing highly skilled immigrants in rural areas: medical professionals in Quebec, Canada in Jentsch, B. and Simard, M. (2009) International Migration and Rural Areas, Cross-National Comparative Perspectives. Surrey, England: Ashgate, Ch. 3 pp.43-74.

Simard, M. and Jentsch, B. Introduction: Key issues in contemporary rural immigration in Jentsch, B. and Simard, M. (2009) International Migration and Rural Areas, Cross-National Comparative Perspectives. Surrey, England: Ashgate, Ch. 1 pp.1-16.

Taylor, C. (1994) Multiculturalism: examining the politics of recognition, Princeton: Princeton University Press. 
Tönnies, F. (1955) Community and association (Gemeinschaft und Gesellschaft) London: Routledge \& K. Paul.

Valdivia, C and Dannerbeck, A. (2009) Immigration Experiences in New Settlement Communities of the Midwest Professional Development: The International Journal of Continuing Social Work Education Vol. 12 No. 3 pp.1-29.

Wallace, A., McAreavey, R., Atkin, K. And Bradshaw, J. (forthcoming 2012) Poverty and Ethnicity in Northern Ireland: an evidence review. York: Joseph Rowntree Foundation.

Weaver, H.N. (1999) Indigenous People and the Social Work Profession: Defining Culturally Competent Services. Social Work/ Volume 44( 3) pp. 217-225. 